\title{
Disaster communication of the Merapi slope community
}

\author{
Ulfah Hidayati
}

Communication Science Department, Faculty of Social Sciences

Universitas Negeri Yogyakarta, Indonesia

Email: ulfah.hidayati@uny.ac.id

Pratiwi Wahyu Widiarti

Communication Science Department, Faculty of Social Sciences

Universitas Negeri Yogyakarta, Indonesia

Email:pratiwi_ww@uny.ac.id

Eko Prasetyo Nugroho Saputro

Communication Science Department, Faculty of Social Sciences

Universitas Negeri Yogyakarta, Indonesia

Email: ekoprasetyo@uny.ac.id

\begin{abstract}
This research aims to examine disaster communication performed by the community of Turgo, Purwobinangun, Pakem. Sleman. The research was conducted utilizing a qualitative method, and the data were collected through interviews and Focus Group Discussions. The research objects include the community members living in Turgo consisting of teenagers, adults, the elderly, the search and rescue (SAR) team, and village heads. The research results show that the people living in Turgo utilize many sources of information in accessing disaster information, including surveillance and reconnaissance posts (wastai posts), social media, interpersonal communication, and group communication.
\end{abstract}


The information is delivered through Whatsapp Group, Youtube, Twitter, Instagram, direct/ face-to-face communication, traditional bamboo slit drum (kentongan), motorcycle horns, and speakers. In addition, the resident's response is very positive in responding to any call/order from the authorities. In other words, no citizen rejected the call given. Also, opinion leaders do not have a significant role in disaster communication. The SAR team has a higher position than the opinion leader as they know the conditions in the field better.

Keywords: Merapi, Disaster Communication, Communication Process

\section{INTRODUCTION}

Mount Merapi located in Central Java is one of the most active volcanoes in Indonesia. According to data from ESDM, this mountain has a high potential for disaster as it erupts every two to five years. Since 1548, the mountain has erupted 68 times. Magelang and Yogyakarta are the nearest major cities, less than $30 \mathrm{~km}$ from the peak. On the slopes, there are still settlements up to an altitude of 1,700 meters and approximately four kilometers from the peak.

Education and Tourism in Merapi and its surroundings have become a determining factor in the city's development. Although it is believed that the Merapi eruption will occur and be dangerous for the people in Sleman Regency, the environment of the Merapi Slope remains attractive for the residential environment and is now densely populated. Sleman is one of the regencies prone to the Merapi eruption. According to PVMBG records, 28 areas in Indonesia are threatened by volcanic eruptions (Siswadi, 2012).

According to Gunawan (2015), the community is the main actor in disaster management due to some reasons: (1) the community directly involves during the process of anticipation (pre-disaster), rescue at the time of the disaster, and the recovery process; (2) the community has the empirical experience during the stay in disaster-prone locations that can be used as a guideline in disaster management; (3) community has values, behavior patterns, and skills in adapting and interacting with its environment that has been constructed hereditarily. In other words, the role (participation) of the community is one of the important elements that determine the success in disaster risk reduction. In the field, the community's existence must be used as a basis.

The results of past-experience learning will shape the pattern of behavior of how the community interacts with its environment. The past experiences deal with the utilization of potential and the problems solving: what to do, 
how to do it, and what not to do. Some of those past experiences are packaged by the community as unwritten guidelines for daily activities and are used as traditions, local wisdom, or culture.

Local wisdom is often referred to as local knowledge. According to Jeniarto (2013), local wisdom has two broad meanings. First, local wisdom is the knowledge of ancestral heritage passed down through tradition. This knowledge is permanent in various eras. Second, local wisdom is local knowledge resulting from local intelligence in dealing with life's problems. This knowledge is constantly changing according to the environment of the times. This knowledge is contextual in different spaces and times. Dekens (2007) states: "A local knowledge system is composed of different knowledge types, practices and beliefs, values, and worldviews. Such systems change constantly under the influence of power relations and cross-scale link".

Local wisdom is a set of knowledge in a community, deriving from past generations and experience concerning the environment and other groups to solve problems or difficulties. Local wisdom can be studied through words of wisdom that have been learned from generation to generation and become a guide for life. Words of wisdom typical of an ethnic group generally utilize one of the main linguistic tools called metaphors. Metaphor is called the primary linguistic tool since it opens the possibility for any language to develop into sophisticated according to the needs of its ethnic group (Martin, Nolte, \& Vitolo, 2016).

An essential thing in disaster management practice is that local wisdom has guided the community to obtain prosperity, under normal conditions, during a disaster, and after a disaster. Soetomo (2012); Dekens (2007); Kusumasari \& Alam (2012): and (Suyuti, 2014) reveal that local wisdom or local knowledge has been used by the community and provide beneficial lessons in disaster management. Also, the importance of local wisdom has been used as one of the topics of discussion in the Fourth Session of the Global Platform for Disaster Risk Reduction di Geneva 2013.

In this digital era, the people of Merapi are exposed to information coming from the internet. Although they have vital local wisdom, the internet that offers ease and great information has impacted the community's attitude in the pre-disaster phase. The communication of the Merapi slope community during the pre-disaster phase is interesting to examine, considering that the Merapi slope community is inseparable from digital media. 
This study investigates how pre-disaster communication is performed by the people in Turgo, Purwobinangun Pakem Sleman. The communication process in this study includes communication patterns, namely interpersonal communication, group or organizational communication, and mass communication. Based on each pattern of communication, how the residents gain information is revealed.

People trust more credible sources of information. Credible sources of information will be more persuasive than less credible sources. As stated by Lorge Petty, 1996, in his research that "a high credibility source was more persuasive than a low credibility source if attitudes were measured immediately after the message." The indicators of trust aspects include being impartial, honest, having integrity, capable, wise, having sincerity, and sympathy (Hidayati, 2020).

This research also investigates how the influence of information obtained from sources on the attitude of the people of Merapi slope. This study used a qualitative approach. Moreover, data were collected using in-depth interviews and focus group discussions. This research also intends to reveal the sources of information used to access information about the pre-disaster of Merapi, the type of information obtained and how the effect of the information on the attitude of the people of the Merapi slopes.

\section{LITERATURE REVIEW}

\section{Communication Process}

Communication can take place primarily or secondary. The primary communication process conveys the ideas and or feelings of an individual to another individual utilizing symbols as the medium. These symbols include language, images, colours, gestures, etc., which explain the ideas and feelings experienced by the communicator to the communicant directly. Meanwhile, the secondary communication process is transmitting messages using tools as a communication medium. In this case, the communicator uses the tool to communicate due to the relatively large number of communicants or the far distance of communicants. E-mail, newspapers, telephones, magazines, television, etc., are examples of media often used in the secondary communication process (Effendy, 2007).

The communication process can be described in a model. The model provides an overview to understand the meaning of a message and deals with 
the fundamental elements, processes, channels, and participants in achieving a particular goal (Ruslan, 2010). One of the communication models is proposed by Harold Lasswell where the communication process is to answer several questions, namely: Who?, Says what?, In which channel?, To whom? With what effect (Effendy, 2007). The Lasswell Communication Model is presented in the following figure.

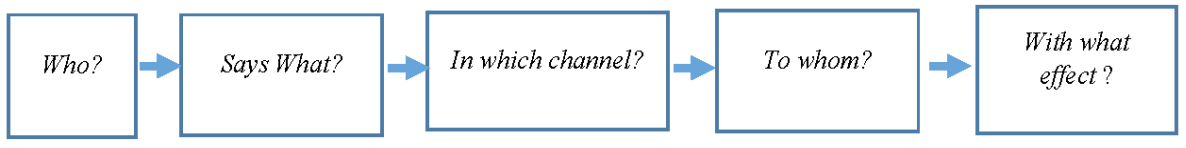

Figure 1. Lasswell Communication Model

Based on Lasswell's communication model, communication is a process of message transmission performed by the communicator to the recipient of the message through specific channels that can cause effects. In addition, the answers to the questions in the Lasswell communication model are elements in communication that include communicators, messages, media, receivers and effects.

\section{Disaster Response Communication}

In dealing with disaster emergencies, communication has a vital role as described by Haddow \& Haddow (2014), where communicating disaster preparedness and mitigation can encourage various actions that can reduce disaster risk. Furthermore, Haddow \& Haddow (2014) describe five main foundations in creating effective disaster communication, which consists of:

1. Costumer Focus, which is to understand what information is needed by the community and volunteers. Communication mechanisms that can ensure accurate and precise information dissemination must be created.

2. Leadership Commitment, which refers to a leader's commitment to communicate effectively and be actively involved in every communication process

3. Inclusion of Communication in Planning and Operations, where communication specialists must be involved in the planning and all emergency operations to ensure information is delivered timely and accurately

4. Situational Awareness, where effective communication can be carried out by collecting, analyzing and disseminating information related to disasters in a controlled manner. Transparency and reliability are the keys to effective communication 
5. Media partnership, where the media plays a vital role in conveying information accurately and precisely to the public. Collaboration with the media can be performed by increasing understanding of the media needs and the teams involved to collaborate in obtaining information and disseminating it to the public.

Disaster communication is needed during disaster emergencies and in pre-disaster times. Haddow \& Haddow (2014) explain that communication is the best way for disaster mitigation, preparation, response, and recovery to be successful. In addition, according to Suherman (2018), disaster risk reduction needs to be supported by soft and hard power approaches. The soft power approach can be realized by providing socialization and information about disasters to the community, while the hard power approach can be realized by building communication facilities, building dams, building concrete walls and other physical infrastructure. In implementing both approaches, disaster communication is needed.

\section{Communication and Disaster Mitigation Based on Local Wisdom}

The utilization of local wisdom in disaster mitigation is performed by the people living around Mount Merapi. Gunawan (2015) explains that local wisdom can be utilized in disaster management. Based on his research, the Merapi slope community has a model that has been well-manifested in the daily behaviour of the community and at certain events such as in the management of natural disasters. This model is constructed hereditarily based on values, norms and ethics to preserve the natural environment.

Furthermore, Gunawan (2015) states that the observation of the people who live in disaster-prone areas indicate that there is still a lot of important information about human behaviour that has not been revealed, especially behaviour that has significance to disaster management. In this case, local wisdom inherited from generation to generation provides information, ideas and materials that can be used as a guide in acting in the present and the future.

\section{The Role of Technology in Disaster Communication}

Rapid technological advances offer a variety of sophisticated facilities that can help humans in managing the impact of disasters by reducing their effects on human life. With the development of communication technology, the use of social media is now important to optimize disaster emergency response and disaster recovery activities. The use of social media also helps to increase the effectiveness of information flow on disaster mitigation so that 
it can create policy synchronization between local governments, districts and villages (Fahriyani et al., 2020)

On the other hand, the advancement of technology that encourages the abundance of information can cause public anxiety because the information circulating can come from various sources, especially if the information comes from unreliable sources. This can cause public confusion so that people also need to have the ability to do fact-finding in order to choose reliable information that can support the disaster mitigation process.

\section{METHODS}

This study examines how the pre-disaster communication process in Turgo Hamlet, Purwobinangun Subdistrict, Pakem, Sleman, Yogyakarta, situated on the slopes of Merapi. The communication process in this study is investigated through several levels of communication, namely interpersonal communication, group communication, and mass communication. Based on each level of communication, the information obtained by residents related to disasters will be revealed.

Data were collected through interviews with nine residents of Turgo Hamlet who represent the young people, adults, the elderly, village officials (opinion leaders) and the Merapi SAR Team. The interview data revealed the disaster communication of the community living on the slopes of Merapi. After performing interviews, the researcher carried out FGD to validate the data collected during the interview.

People will trust more credible sources of information. Credible sources of information will be more persuasive than less credible sources. Lorge Petty (1996) states that "a high credibility source was more persuasive than a low credibility source if attitudes were measured immediately after the message. Trust has some indicators such as being neutral, honest, having integrity, capable, wise, having sincerity and sympathy (Hidayati, 2019).

This study also examines how the obtained information from sources impacts people's attitudes in the Merapi slope. This research employed a qualitative approach with data collection techniques using in-depth interviews and Focus Group Discussion (FGD). Through this research, some aspects were investigated, namely information sources used to access information about the Merapi disaster, the type of information obtained, and how the effect of the information on people's attitudes in the Merapi slope. 


\section{RESULTS AND DISCUSSION}

Communication is an intentional act to convey a message to meet the communicator's needs, such as explaining something to another person or persuading him to do something. The conceptualization of communication as a one-way action highlights the effective delivery of messages and implies that all communication activities are instrumental and persuasive (Mulyana, 2007: 67). In the context of delivering information about the Merapi disaster to the public, communication is viewed as a process of message delivery and as oneway action.

In addition, this study also utilizes the communication model proposed by Harold Lasswell. According to Laswell, to describe the communication process is to answer several questions: Who?, Says What?, In which channel? To Whom?, With what effect (Effendy, 2007). So this study uses communication elements consisting of (a) the source of the message, namely the media used to obtain information about the Merapi disaster, whether from the mass media, interpersonal communication, or from other sources of information (b) message, namely information about the Merapi disaster (c) the recipient of the message, namely the residents of Turgo Hamlet, and (e) the effect, namely the attitude of the residents when the Merapi disaster occurred.

\section{Sources and Information Dissemination Media}

In performing disaster communication, the community of the Merapi slopes (Turgo Hamlet) use some sources of information, including social media, interpersonal communication, group communication, and wastai post (surveillance and reconnaissance post).

Social media used as sources of information include official Youtube, Twitter, and Instagram accounts of Volcano Investigation and Development Center (locally known as BPPTK) and National Disaster Management Agency. Social Media is used to obtain detailed information from the initial information they receive. Citizens get initial information from private posts or interpersonal communication. Then, they access social media to get further information. Young people and adults tend to access social media because it is more accessible and practical.

Some residents also obtain information from interpersonal communication with family, relatives or neighbours. When residents see firsthand the dan- 
gerous condition of Merapi, they immediately report it to family or neighbours. Apart from that, group communication through Whatsapp Group of Turgo residents also became one of the sources of disaster information. Information was also conveyed from Merapi Volunteers (SAR Team) regarding the current condition of Merapi. The SAR Team also shared information obtained from BPPTK to residents. In the Whatsapp Group, anyone gets the same role as a source of information. The village officer (opinion leader) does not get a higher position than its citizens in disaster communication.

Residents also consider the wastai post an essential source of information. The SAR team and volunteers were ready to guard for 24 hours when Merapi was in danger. The wastai post is equipped with kentongan and speakers. When the condition of Merapi increases, the volunteers at the wastai post inform the residents through the media. The sound of kentongan also has certain meaning, when kentongan is hit with a rhythm of two by two, residents should be alert. However, when it is hit with an intense rhythm, the residents must immediately move to the gathering point.

In addition to kentongan and speakers, motorcycle horns are also used to notify residents in the valley or forest because the sound of loudspeakers and kentongan may not reach residents in the location. Volunteers will also immediately check each residentss home, anticipating whether residents do not know the information. This action aims to ensure that all residents are ready to be evacuated.

Turgo residents also use Handy Talky (HT) to facilitate disaster communication. Even $40 \%$ of residents use it. HT was chosen as the medium to communicate because of its signal stability compared to mobile phones or smartphones. HT does not use an internet signal but a VHF (Very High Frequency) signal, so it is more suitable for mountainous areas where the internet signal is difficult. When the condition of Merapi begins to improve, volunteers and the SAR Team will patrol the wastai post to monitor the condition of Merapi directly. The information they get will be delivered through HT so that residents can respond immediately. In addition, HT is also connected to seismographs in Merapi. From this connectivity, residents can listen to Merapi's activities from the voice of HT. When HT's voice is calm, Merapi's activities are calm. However, Merapi's activity increased when HT's voice was loud and noisy.

\section{Information About Disasters Obtained from Information Sources}

Residents of Turgo Hamlet get various kinds of information about the 
Merapi disaster from various sources. Based on the interviews, the information obtained from social media includes further or detailed explanations or details of the initial information. The initial source of information referred to here is information from private posts and interpersonal communication. After obtaining information from the initial source, residents check and re-check it on social media of BPPTK to get more complete and clearer information. For example, when the wastai post calls on residents to immediately move to the gathering point, residents will find out the detailed information such as the magnitude of the earthquake scale, the direction of lava fall, the potential of hot clouds, and so on through the media.

In addition, residents get information about the dangers of Merapi in general, not in detail, from interpersonal communication with neighbors or relatives. For example, the invitation to immediately prepare to evacuate, bring valuable belongings and prepare supplies during the evacuation. Similar information was also provided by the SAR Team from Wastai Post. The wastai post containing the volunteers and the SAR team became the first source of information ordering to immediately move to the gathering point. The SAR team has the authority to move residents to the gathering point, while the decision to evacuate residents is determined by the BPPTK. However, in certain (very emergency) conditions, the SAR Team is authorized to issue an evacuation decision.

\section{c. Community response after obtaining information from sources}

All respondents in this study responded positively to any information received from sources by carrying out any call or command given. In fact, since the eruption in 2006, there was no residents who refused to be evacuated. The eruption of 2006 was the largest eruption of Merapi that killed the Merapi Guards Figure (Mbah Marijan) so that it provided many valuable lessons for the residents of the Merapi slopes.

\section{Obstacles and solutions during the disaster communication process}

There are several obstacles faced by residents during the disaster communication process. The obstacles and solutions are described as follows.

1. Low mobile phone signal (HP)

Turgo is located in a mountainous area so the internet and mobile phone signal are bad. This can hinder the communication process. Therefore, residents also use handy talky (HT). This HT is very suitable for 
the conditions of Merapi. HT signals that use VHF are more stable than internet signals. In fact, up to now, $40 \%$ of residents use HT because of its effectiveness.

2. The unreach disaster information

When the Merapi condition is critical, the SAR Team will sweep the residents' houses to ensure that all residents get required information because sometimes there are people who are sleeping or sick so they don't know about the critical condition of Merapi. In addition, for residents who are out of reach of information sources (in the valley or forest), the volunteers go to the streets of the forest edge by repeatedly honking motorcycle horns. Residents already know every sign that is conveyed so they will respond immediately.

\section{Power Off}

When the electricity is off and the electronic communication facilities do not work, the traditional communication equipment (kentongan) is used. In addition, the motorcycle horn that sounded repeatedly is also a sign that Merapi is in critical condition. One of the informants stated that the residents used bende (like a big gong) as an information medium when electricity did not reach the slopes of Merapi. This traditional medium is placed at the Plawangan Post in a high place. Some are on duty at the Plawangan Post every day. When Merapi is in critical condition, those who patrol will hit them.

\section{The Role of Opinion Leaders in Disaster Communication}

The opinion can express their opinions by using mass media channels. For example, Lazarsfeld, Berelson, and Gaudet (1948) argue that opinion leaders, who actively collect information from the mass media, incorporate their own values and views into that information, and then disseminate them to consumers around them in daily life (Master of Communication Program, \& Undip, 2014).

In relation to disaster communication, the opinion leaders (village officers) do not have a higher role than other residents of Turgo Hamlet. The village head will follow the instructions given by the SAR/ Volunteer Team as the person who knows the best conditions in the field. The SAR Team's communication to the hamlet head is limited to reporting and the hamlet head gives full authority to the SAR Team to take a decision. With such conditions, 
the SAR Team has a higher authority than the opinion leader in relation to disaster communication.

\section{CONCLUSION}

In disaster communication, Turgo villagers used several sources of information, namely: surveillance and reconnaissance posts (wastai posts), social media (YouTube, Twitter, and IG), interpersonal communication (with family or neighbors), and group communication through Whatsapp Group residents of Dusun Turgo. In addition to social media, traditional media is also used, namely kentongan. Detailed disaster information is obtained from social media. Residents will get information for the first time from the wastai post or interpersonal communication. Additional information is also obtained from group communication via Whatsapp Group. Through wastai posts and interpersonal communication, residents gain knowledge related to the current conditions of Merapi, calls to immediately move to the gathering point or evacuation, and prepare items that will be brought during the evacuation. In the future, this research will be developed by using communication network analysis so that more complete data related to disaster communication will be obtained.

\section{REFERENCES}

Dekens, J. (2007). Local knowledge for disaster preparedness: A literature review. International Centre for Integrated Mountain Development (ICIMOD).

Effendy, O U. (2007). Ilmu komunikasi teori dan praktek. PT Remaja Rosdakarya.

Fahriyani, S., Harmaningsih, D., \& Yunarti, S. (2020). Penggunaan media sosial Twitter untuk mitigasi bencana di Indonesia. IKRA-ITH HUMANIORA: Jurnal Sosial dan Humaniora, 4(2), 56-65.

Gunawan, G. (2015). Kearifan masyarakat lereng Merapi bagian selatan, Kabupaten Sleman-Daerah Istimewa Yogyakarta. Sosio Informa, 1(2). 189. 212

Haddow, K. S., \& Haddow, G. D. (2014). Disaster communications in a changing media world (2nd ed.). Elsevier.

Hananto, P. (2014). Opinion leader versus new opinion leader dalam komunikasi pemasaran (studi kasus selebtwit di twitter untuk komunikasi 
pemasaran). Interaksi: Jurnal Ilmu Komunikasi, 3(2), 140-153.

Hidayati, U. (2019). The political communication process among Chinese moslem society. Informasi, 42(2), 125-143. http://doi.org/10.21831/ informasi.v49i2.27989

Jeniarto, J. (2013). Diskursus local wisdom: Sebuah peninjauan persoalanpersoalan. Ultima Humaniora, 1 (2), 1-14.

Kusumasari, B. \& Alam, Q. (2012). Local wisdom based disaster recovery model in Indonesia. Disaster Prevention and Management, 21(3). 351- 369.

Martin, E., Nolte, I., \& Vitolo, E. (2016). The four Cs of disaster partnering: Communication, cooperation, coordination and collaboration. Disasters, 40(4), 621-643.

Ruslan, R. (2010). Manajemen public relations \& media komunikasi. PT Raja Grafindo Persada

Siswadi, A. (2012). 28 kota Indonesia terancaman gunung api. Retrieved 02 13, 2015, from Tempo.Co: http://www.tempo.co/read/ news/2012/09/28/061432419/28-Kota-Indonesia-TerancamLetusanGunung-Api.

Soetomo, S. (2012). Kewaspadaan masyarakat, manifestasi kapasitas masyarakat untuk berkembang secara mandiri. Pustaka Pelajar.

Suherman, A. (2018). Strategi komunikasi bencana pada masyarakat Kabupaten Buton Selatan. Medialog: Jurnal Ilmu Komunikasi, 1(2), 10-18.

Suyuti, H. (2014). Yogyakarta city disaster risk resilience living in harmony. In Presented for 'Increasing the Resilience of Cities in the Middle East and North Africa', MENA Urbanization Knowledge Platform Conference. Marseille, France-May (pp. 22-23). 
Informasi, Vol. 51. No. 2. (2021), 267-280 